\title{
Understanding Teacher Authority
}

\author{
Linqiong $\mathrm{Lü}^{1} \&$ Jiaqiang $\mathrm{Hu}^{2}$ \\ ${ }^{1}$ School of English Education, Guangdong University of Foreign Studies, Guangzhou, China \\ ${ }^{2}$ School of Foreign Studies, South China Normal University, Guangzhou, China \\ Correspondence: Linqiong Lü, School of English Education, Guangdong University of Foreign Studies, \\ Guangzhou, 510420, China. Tel: 86-135-7058-6896.
}

Received: January 6, 2021

Accepted: June 1, 2021

Online Published: August 4, 2021

doi:10.20849/jed.v5i2.916

URL: https://doi.org/10.20849/jed.v5i2.916

\begin{abstract}
Despite the fact that teacher authority is an ever-present and fundamental component of everyday school life and classroom experiences, teacher authority remains poorly understood and insufficiently researched. By reviewing the sociological and educational literature on teacher authority, the study outlined the current status of teacher authority research, explicated the institutional and personal sources of legitimate teacher authority, and delineated four perspectives for understanding teacher authority: a) teacher authority is legitimate domination generated and justified by professional and personal sources of legitimacy; b) teacher authority functions through pedagogical discourse which is a both instructional and regulative process of transmitting value-laden knowledge; c) teacher authority is in dynamic teacher-student relationships where teachers cannot automatically possess but have to earn students' respect; d) teacher authority emits educational influences and essentially serves the moral order of conscience. The study calls for more research into teacher authority especially against the backdrop of declining teacher authority yet ever growing expectations and demands on teachers and teaching outcomes.
\end{abstract}

Keywords: authority, power, teacher authority, teacher-student relationship, sociology of education

\section{Introduction}

Teacher authority is a thorny, poorly understood yet ever-present and fundamental component of everyday school life and classroom experiences (Pace \& Hemmings, 2007). Teacher authority is thorny because it carries both positive and negative overtones. For some, authority could refer to glamorous leadership rooted in a leader's charisma and acclamation. For others, it might be a synonym for domination and manipulation exercised by power holders to obtain involuntary obedience from those less powerful ones (Alderman \& Green, 2011; Harjunen, 2009; Uitto \& Syrja La, 2011). Despite its elusiveness, controversies and complexities, a growing body of theoretical and empirical research has convincingly demonstrated that teacher authority is an ever-present feature of everyday school life, determining the quality of students' schooling experiences (Koutrouba, Baxevanou, \&Koutroumpas, 2012; Pellegrino, 2010; Richmond \& McCroskey, 1984; van Manen, 1991). However, due to the fast development of information technology and mass media communication, teachers are no longer regarded as primary knowledge holders and distributors and teacher authority is on the decline worldwide (Gordon, 2005; Kelchtermans, 2005; Kitchen, 2014). Meanwhile, educational reforms advocating egalitarian teacher-student relationships make teacher authority a somewhat reluctant topic to be explicitly addressed in school or academia. Authority in teacher-student relations in general is insufficiently researched and under-theorized (McLaughlin, 1991; Ruddock \& Flutter, 2000). This study attempts to fill the paucity and aims to provide a more balanced and comprehensive view of teacher authority.

\section{Methods}

The authors conducted a theoretical exploration of teacher authority in three steps. First, they searched the articles and works published in the last 20 years. Using the key words like "teacher authority", "classroom authority", and "pedagogical authority" in the field of title, they searched the databases of Social Science Premium Collection, ERIC, ProQuest Central, Taylor \& Francis Online, JSTOR Archival Journals, Sage Publications, and ScienceDirect and identified 147 peer-reviewed articles related to the themes of education, teacher, teaching and learning. Second, according to the citations in the articles, they further identified the salient works related to power (e.g. Foucault, 1979, 1980, 1982; Hofstede, 2008), authority (e.g. Weber, 2008), classroom authority (e.g. Metz, 1987; Pace \& Hemmings, 2006) and pedagogical discourse (e.g. Bernstein, 
1996). By conducting careful analysis of the literature, they finally developed themes for discussing teacher authority. The following sections are thematically organized into four parts, namely, state of art of teacher authority research, definition of teacher authority, sources of authority, and four perspectives of teacher authority.

\section{State of Art of Teacher Authority Research}

In the field of education, teacher authority is often conflated as control strategies of sanctions and rewards used for disciplining students (e.g., Blatchford, Bassett, Brown, \& Webster, 2009; Cross et al., 2011; McCluskey et al., 2008; Munn et al., 2011). The thorny and paradoxical feature of authority as a type of power may partly originate from the socio-psychology for power being exercised, as Hofstede (2008: 83) puts it, "The need for independence in people is matched by a need for dependence and the need for power by a need for security". People need authority for leadership, directions, and security with the similar desire for equality, autonomy, freedom, and independence. The controversy, therefore, may not so much rest upon authority itself but how authority is exercised as a form of power. Similar to the dialectics between democracy and despotism, even the emancipatory teaching and learning process does not mean lassie-faire. Discipline combined with guidance, influence, and modeling is the way through which legitimate teacher authority may take place. A more balanced, comprehensive view of authority needs to be included (Macleoda, Macallisterb, \&Pirriec 2012).

Despite pervasive and perennial debates over teacher authority, educational researchers seem to be reluctant to explicitly address the topic. Authority in teacher-student relations in general is insufficiently researched and under-theorized (McLaughlin, 1991; Ruddock \& Flutter, 2000). There is a large body of research scrutinizing classroom interaction and teacher-student relationship. However, "these studies have not included explicit and theoretically grounded analysis of student-teacher authority relations" (Pace \& Hemmings, 2007: 5).

After a thorough review of studies on authority contributed by sociologists, educationalists, and classroom researchers, Pace and Hummings (2007) conclude that authority is a social construction fundamental to the quality of classroom learning, having a great impact on teachers' work and students' educational experience. Rather than a unilateral form of power executed by "powerful" teachers, authority perceived from a sociocultural lens is a relationship mutually constructed by teachers and students; it is influenced by reform agenda and debates, and taking disparate forms in varying contexts (Anyon, 1983; Hemmings, 2003; Hemmings \& Metz, 1990; Metz, 1978; Oakes, Gamoran, \& Page, 1992; Pace, 2003a, 2003b, 2003c, 2006; Pace \& Hemmings, 2006). Legitimate authority is functional and crucial for effective teaching and learning (Koutrouba, Baxevanou, \&Koutroumpas, 2012; Pellegrino 2010; Richmond \& McCroskey, 1984). Despite the insights offered by the existing body of literature in terms of the attributes of teacher authority, the question of how teachers construct and maintain teacher authority in different contexts remain largely unanswered (Harjunen, 2009; Nathan, 2012). Pace and Hummings (2007) call for more in-depth qualitative research to be conducted in diverse contexts to unfold the situated complex and dynamic process of constructing and enacting teacher-student authority relationships.

\section{Definition of "Teacher Authority"}

Researchers adopt various terms to name authority relations between teachers and students: "teacher authority" (Pace \& Hemmings, 2006; Tirri \&Puolimatka, 2000), "classroom authority" (Oyler \& Becker, 1997; Pace \& Hemmings, 2007), "authority in student-teacher relations" (Macleoda, MacAllisterb, \& Pirriec, 2012), "pedagogical authority" (Harjunen, 2009, 2011), and "legitimate teacher authority" (Lai, Gu, \& Hu, 2015). The present research sticks to "teacher authority" for two reasons: First, to focus on the active role that teacher can take in authority construction and operation; second, to avoid the probable narrowing down of teacher authority to one particular aspect implicated by the terms such as "pedagogical authority".

The literature review of the western theories of power and authority and classroom research of teacher authority yields a systematic conceptualization of teacher authority. There are five essential claims of the western sociology of teacher authority (Pace \& Hemmings, 2006: 2)

Claim 1: Classroom authority in its truest form depends on teachers' legitimacy, students' consent, and a moral order consisting of shared purposes, values, and norms.

Claim 2: Authority is multiple in its forms and types and the ways in which it is interpreted.

Claim 3: Authority is enacted through dynamic negotiations between teachers and students that often involve overt or subtle conflict.

Claims 4: Authority is situated in various arenas - such as curricula and classroom discourse - and is shaped by multiple interacting influences, including varying perspectives on educational purposes, values, and norms; school ethos and policy; teachers' knowledge; institutional features of schooling; and historical context. 
Claim 5: Authority is consequential for classroom life, students' achievement, teachers' work and democracy.

Drawing on the existing body of research, the authors proposed the following definition of teacher authority:

"Teacher authority" in the present research is defined as a form of non-coercive power which is endorsed by students due to its perceived legitimacy and constructed by dynamic teacher-student relations centering on a moral order; it is essentially a type of symbolic control that translates power relations into pedagogic discourse and pedagogic discourse into power relations.

\section{Sources of Authority}

\subsection{Max Weber's Theory of Authority}

Max Weber could be the first sociologist in the history who provides a systematic analysis of authority in terms of its sources of legitimacy in the late 1910s (Dreijmanis, 2008). He considers that the "inward justification" of authority comes from its traditional, charismatic, and rational-legal sources which constitute accordingly three types of authority.

"Traditional authority" is based upon custom which incurs habitual observation of traditional rules set forth by and passed on from the ancestor. Traditional authority is typical of a patriarchal society where the gurus and parents expect their juniors' respect and obedience due to the very fact that there exists the tradition of hierarchical deference and compliance. "Charismatic authority", according to Weber, is entirely "personal" and rooted in the extraordinary leadership qualities of a person. The prophet and the political leader may possess and exercise their charismatic authority to obtain people's conviction and allegiance. "Rational-legal authority" obtains its validity and competence from the status and rules promulgated by the state or an institution. The obedience of the law or rules is regarded as the fulfillment of the duty of every member. It is, therefore, the type of authority which realizes a contractual relationship between the modern state (or institution) and its citizens (or staff).

\subsection{Revision of Max Weber's Theory}

Since Weber, there are numerous efforts of revision and refinement of his typology of authority. An important refinement was conducted by Rodney Clifton and Lance Roberts (1990). Their revision is twofold. First, they added "expertise" as one source of authority and thus actually raised the concept of "professional authority". Weber actually mentioned "disciplinary authority" in his writings on academia but he did not include professional competence and qualification as part of the sources contributing to legitimate authority. Second, they proposed two upper categories of "the institutional authority" and "the personal authority". The institutional authority includes the traditional and rational-legal authority; the personal authority subsumes the professional and charismatic authority. Figure 1 depicts the teacher authority constitution proposed by Clifton and Roberts:

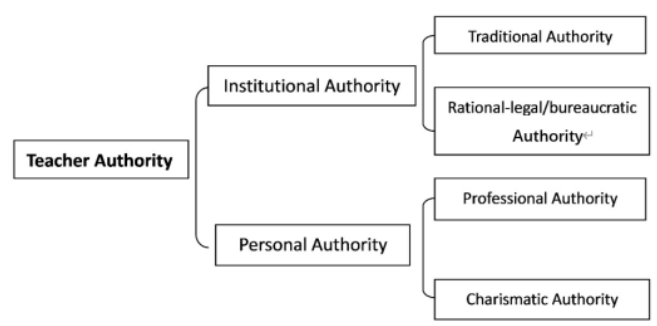

Figure 1. Teacher authority constitution

For the study of teacher authority, a question left behind is: What exactly is "charismatic authority"? Mary Metz (1978), the pioneer in the research of teacher authority in the western academia, underscored the professional and moral aspects of the teaching profession. She considered "professional authority" as originated from teachers' subject knowledge and pedagogical expertise and "moral authority" as residing in the embodiment of teacher as role model with good conducts and virtues. Charisma thus can emanate from both teachers' professional and moral authority.

\section{Four Perspectives About Teacher Authority}

When addressing authority as a special type of power, its legitimacy and validity are emphasized. The superordinate obtains the consent of the subordinates for his rule which complies with rather than opposes the 
will of the subordinates (Barnard, 1950). In the field of education, Mary Mets (1978: 26) provides the definition of teacher authority as follows:

Authority is distinguished ... by the superordinate's right to command and subordinate's duty to obey. This right and duty stem from the crucial fact that the interacting persons share a relationship which exists for the service of a moral order to which both owe allegiance. This moral order may be as diffuse as the way of life of a traditional society or as specific as the pragmatic goals of a manufacturing organization. But in any case, all participants have a duty to help realize the moral order through their actions.

Mets' definition actually emphasizes the rational legal restraint of "moral order" in establishing the right-duty relationship of subordination between teachers and students. A moral order is composed of shared norms, values, and principles of being good and able to hold individuals together as a whole for realizing common goals (Hemmings 2006; Sedlak, Wheeler, Pullin, \& Cusick, 1986). The more commonly recognized and endorsed the moral order, the more allegiance and stability it obtains and achieves.

By integrating postmodern theory of power and various individual studies on authority and teacher authority, we intend to arrive at a more comprehensive understanding of teacher authority addressed from four perspectives: a) teacher authority as legitimate domination; b) teacher authority as knowledge/power intimacy; c) teacher authority as dynamic teacher-student relationships; d) teacher authority as moral service. The following sections elucidate each of the perspectives.

\subsection{Perspective 1: Teacher Authority as Legitimate Domination}

Authority is by all means a type of power. "Power" is defined as "the potential to determine or direct (to a certain extent) the behavior of another personal or other persons more so than the other way round" (Mulder, 1977). The greater the extent to which the subordinates accept and expect that power, the more powerful the superordinate becomes (Hofstede, 2008). Due to the differentiated abilities, expertise, prestige, social norms, etc., "inequality in power is inevitable and functional" (Hofstede, 2008: 79). Power inequality is inevitable and functional in social life and can be both valid and invalid dependent on whether it is expected and accepted by the less powerful members (Ibid.). The operation of power is based upon the socio-psychology of the duel needs of dependence for security and independence for autonomy: "Dependence and security step from early childhood and are common to all human beings; independence and power are developed only later in lives, if they are developed at all." (Ibid.: 83). As Wrong (1980) states, "Submission to power is thus the earliest and most formative experience in human life" (p.3), human beings have been and are constantly being trained in dominance or submission (Bateson, 1973, originally 1942). These statements reflect van Manen's (van Manen, 1991) observation: Life in general and the pedagogical world in particular is full of contradictions one of which is freedom (in the form of independence, autonomy, and liberty) versus control (in form of order, discipline, and system).

For a comprehensive understanding of power, the three related concepts, namely, domination, authority and legitimacy, need to be considered together (Hearn, 2012). As mentioned in the previous section, the sociological study of authority is rooted in the work of Max Weber (1978) who examined "ideal types of authority" rooted in different sources of legitimacy and defined them as "legitimate domination" (Macleoda et al., 2012): Domination becomes authority if it is in compliance with the dominated people's beliefs and perceived as righteous and valid. To put it another way, to say somebody has authority means that s/he has the competence to gain consent and have his/her orders obeyed. To say someone has authority means s/he has successfully established "a communicative relationship, however broadly defined, between the givers and the receivers of orders" (Hearn, 2012: 23). Authority in Weber's line of thinking is a justified relationship of domination and obedience.

\subsection{Perspective 2: Teacher Authority as Knowledge/Power Intimacy}

There are two dimensions of teacher authority: the teacher being an authority and in authority (Peters, 1966). Perceived as the embodiment of knowledge, teachers obtain teacher authority the moment they step into the classroom explicitly or implicitly announcing themselves as "teacher". As an apparent authority of knowledge, they obtain the initial consent from students to excise power. The relationship between being an authority and in authority may be best explained within Foucault's (Cordon, 1980) concept of knowledge/power. Foucault's archeology of knowledge explores the relationship between social practices and social disciplines. In his view, the "science" or disciplinary knowledge is not apparently neutral and innocent as it seems to be. General models and first principles of, for instance, justice and peace, are in fact "will to knowledge" (Foucault, 1972) which is often intended to function like "reason" and "truth" but could actually be plural, willful and imposing, constituting simultaneously the danger and a tool against the danger. Enmeshed in all kinds of domination, trivial or tremendous, are the "knowledge" subjugating individuals into controllable subjects. 
The Foucauldian conceptualization of power and knowledge resonates with Bernstein's $(1975,1990,1996)$ notion of pedagogical discourse which consists of two discourses: instructional discourse for transmission of competence and regulative discourse for transmission of moral values. The legitimated forms of knowledge and legitimated forms of power are in service of the same regulatory mechanism. Though most people study them as separate two discourses, Bernstein (1996) contends that there is only one regulative moral discourse that dominates and "creates the criteria which give rise to character, manner, conduct. In school it tells children what to do, where they can go" (p. 46-48).

\subsection{Perspective 3: Teacher Authority as Dynamic Teacher-Student Relationships}

Foucault (2001) maintains that power does not exist by itself; rather, it exists in relations and is expressed in action. His assertion shifts our attention from power as an object being possessed to power as dynamic relations actualized by specific power construction practices. Gore's (1998) research has focused on the mechanism of schooling, i.e., the institutional exercise of power by the school regime, by identifying and demonstrating those practices that actualize the shifting power movements between a teacher and students.

Though "authority" explicated in the previous sections is often assumed or desired to be "legitimate domination" with sources of legitimacy, there could be no proof that teachers' authoritarian use of power as knowledge authority in everyday classrooms is always justified. In the educational field, the long-standing tension between positive and negative aspects of authority may root in the confusion of teacher as pedagogical authority with teacher's authoritarian use of power (Harjunen, 2009; van Manen, 1991). Authority involves three components: the bearer of authority, its subject and the relevant field (Tirri \& Puolimatka, 2000). Authority could be misused in terms of its subject and the field: A teacher may neither have the right to reprimand parents in public if their children break rules nor does s/he possesses the legitimacy to punish students failing in exams by a heavy fine. The existence of teachers' invalid practices of using authority may give rise to the controversy of "teacher authority" as a slippery notion sitting between legitimacy and domination. The question of what is legitimate teacher authority or legitimate exercise of teachers' authoritarian power is essentially value-laden.

\subsection{Perspective 4: Teacher Authority as Moral Service}

Teacher authority is a set of relationships mutually constructed by a teacher (as an order giver) and students (as order receivers) to influence the moral service of education. The meaning of "moral" derives from its noun form of "morality" which "constitutes a set of a person's beliefs and understandings which are evaluative in nature: that is, which distinguish, whether consciously or unconsciously, between what is right and wrong, good and bad" (Buzzelli \& Johnston, 2001: 876). Education in general and teacher-student interactions in specific are inevitably and fundamentally moral in nature (Ball \& Wilson, 1996; Goodlad, Soder, \& Sirotnik, 1990). Teachers are "moral agents" (Bergem, 1990; Johnston, Juhasz, Marken, \& Ruiz, 1998) doing "moral actions" (Tom, 1984) of reproducing institutionally endorsed legitimate forms of knowledge. As Apple (1982) observes sharply, "schools allocate people and legitimate knowledge. They legitimate people and allocate knowledge" (p. 42).

Based on the moral understanding of teaching and the work of social theorists such as Weber and Durkheim, Mary Haywood Metz (1978) define "teacher authority" as a teacher's right to command and students' duty to obey. van Manen (1991) regards it "another name for moral service" (pp. 69-70), i.e., the student attributes the responsibility of teaching to a teacher. This right and duty are rooted in the fact that teachers and students are in the common pursuit of "a moral order" to which both owe allegiance and have a duty to help realize it through their mutual actions (Pace \& Hemmings, 2007: 26). Similar to Weber (1947: originally 1925), Barnard (1950) emphasizes "legitimacy" of teacher authority, i.e., teachers are able to carry out directions and orders due to the fact that students expect them to do so and are willing to follow.

The unequal hierarchical relationship is justified by "moral orders" which are constituted by shared purposes, values and norms to realize the common goal of, for instance, effective learning (Hemmings, 2006; Sedlak et al., 1986). As Spady and Mitchell (1979) state, students "respond to influence as authoritative when they perceive in an encounter the opportunity to realize their own significance, not merely to satisfy the intentions of someone else (e.g., their parents and teachers) because of the attractiveness or threat of external resources" (101-102). Teacher authority viewed in the moral and positive vein is to influence students to realize their own development (Harjunen, 2009). Teacher authority makes it possible for teachers to issue binding directives of social rules which form a framework for effective teaching and learning to happen (Hemmings, 2006; Neiman, 1986; Selznick, 1992). Teachers enjoy stronger authority when they can arouse students' allegiance to a moral order. Their authority may decrease or diminish if the moral order is unsettled or resisted. 


\section{Conclusion}

Against the backdrop of declining teacher authority worldwide, this study highlighted that teacher authority as legitimate domination is a crucial component for students' school life experiences and overall development. Teacher authority can be better understood from the following four perspectives: a) Teacher authority gains its legitimacy from professional sources of tradition and institutional regulations and personal sources of expertise and charisma; b) Teacher authority functions through pedagogical discourse which legitimates forms of knowledge and justifies forms of power; c) Teacher authority is not so much a power possessed by teachers but resides in dynamic teacher-student relationships constructed by teachers' educational practices and students' concurrent reactions toward them; d) Teacher authority constitutes a moral order pursued and complied by both teachers and students for better effects of teaching and learning. The study called for more research efforts into the thorny yet important educational component of teacher authority.

\section{Acknowledgement}

The research was supported by National Research Fund of Chinese Ministry of Education (Project Number: 18YJC880064).

\section{References}

Alderman, G. L., \& Green, S. K. (2011). Social powers and effective classroom management: Enhancing teacher-student relationships. Intervention in Schooling and Clinic, 47(1), 39-44. https://doi.org/10.1177/1053451211406543

Anyon, J. (1983). Social class and the hidden curriculum of work. In H. Giroux, \& D. Purpel (Eds.), The hidden curriculum and moral education (pp. 143-167). Berkeley, CA: McCutchan.

Ball, D. L., \& Wilson, S. M. (1996). Integrity in teaching: Recognizing the fusion of the moral and intellectual. American Educational Research Journal, 33, 155-192. https://doi.org/10.3102/00028312033001155

Barnard, C. (1950). The functions of the executive. Cambridge, MA: Harvard University Press.

Bateson, G. (1973). Moral and national character. In G. Bateson (Ed.), Steps to an ecology of mind (pp. 62-79). London: Paladin Granada.

Bergem, T. (1990). The teacher as moral agent. Journal of Moral Education, 19, 88-100. https://doi.org/10.1080/0305724900190203

Bernstein, B. (1975). Class and pedagogies: visible and invisible. In Class, codes and control (p. 3, pp. 116-156). London: Routledge.

Bernstein, B. (1990). The structuring of pedagogic discourse. In Class, codes and control (p. 4). London: Routledge.

Bernstein, B. (1996). Pedagogy symbolic control theory, research critique. Bristol, PA: Taylor \& Francis.

Blatchford, P., Bassett, P., Brown, P., \& Webster, R. (2009). The effect of support staff on pupil engagement and individual attention. British Educational Research Journal, 35(5), 661-686. https://doi.org/10.1080/01411920902878917

Buzzelli, C., \& Johnston, B. (2001). Authority, power, and morality in classroom discourse. Teaching and Teacher Education, 17(8), 873-884. https://doi.org/10.1016/S0742-051X(01)00037-3

Clifton, R., \& Roberts, L. (1990). The authority of teachers: a sociological perspective.

Cordon, C. (1980). Power/knowledge: Selected interviews and other writings 1972-1977. New York: Pantheon Books.

Cross, D., Monks, H., Hall, M., Shaw, T., Pinyabona, Y., Erceg, E., ... Lester, L. (2011). Three-year results of the Friendly Schools whole-of school intervention on children's bullying behavior. British Educational Research Journal, 37(1), 105-129. https://doi.org/10.1080/01411920903420024

Dreijmanis, J. (2008). Max Weber's complete writings on academic and political vocations. New York: Algora Publishing.

Foucault, M. (1979). Discipline and punish. New York: Vintage Books.

Foucault, M. (1980). Powers and strategies. In C. Gordon (Ed.), Power/knowledge: Selected interviews and other writings 1972-1977 (pp. 134-145). New York: Pantheon Books.

Foucault, M. (1982). The subject and power. In H. Dryfus, \& P. Rabinow (Eds.), Michel Foucault: beyond 
structuralism and hermeneutics (pp. 208-226). Chicago: The University of Chicago Press.

Foucault, M. (2001). The subject and power (J. D. Faubion, Trans.). In J. D. Faubion (Ed.), Essential works of Foucault 1954-1984 (pp. 326-348). New York: The New Press.

Goodlad, J. I., Soder, R., \& Sirotnik, K. A. (1990). The moral dimensions of teaching. San Francisco: Jossey-Bass.

Gordon, J. A. (2005). The crumbling pedestal: Changing images of Japanese teachers. Journal of Teacher Education, 56(5), 459-470. https://doi.org/10.1177/002248710528257 9

Gore, J. M. (1998). On the limitsof empowerment through critical and feminist pedagogies. In Power/knowledge/pedagogy: The meaning of democratic education in unsettling times (pp. 271-288). Boulder, CO: Westview Press. https://doi.org/10.4324/9780429498060-14

Harjunen, E. (2009). How do teachers view their own pedagogical authority?. Teachers and Teaching: Theory and Practice, 15(1), 109-129. https://doi.org/10.1080/13540600802661345

Hearn, J. (2012). Theories of power. Basingstoke, Palgrave: Macmillan. https://doi.org/10.1007/978-1-137-02202-8

Hemmings, A. (2003). Fighting for respect in urban high schools. Teachers College Record, 105, $416-437$. https://doi.org/10.1111/1467-9620.00245

Hemmings, A. (2006). Moral order in high school authority: dis/enabling care and (un) scrupulous achievement. In J. L. Pace, \& A. Hemmings (Eds.), Classroom authority: Theory, research and practice (pp. 135-150). London: Lawrence Erlbaum Associates, Inc. https://doi.org/10.4324/9781410617163-11

Hemmings, A., \& Metz, M. H. (1990). Real teaching: How high school teachers negotiate national, community, and student pressures. In R. Page, \& L. Valli (Eds.) Curriculum differentiation: Interpretive studies in U.S. secondary schools (pp. 91-111). Albany: State University of New York Press.

Hofstede, G. (2008). Consequences of culture: Comparing values, behaviors, institutions and organizations across nations (2nd ed.). Shanghai: Shanghai Foreign Language Education Press.

Johnston, B., Juhasz, A., Marken, J., \& Ruiz, B. R. (1998). The ESL teacher as moral agent. Research in the Teaching of English, 32, 161-181.

Kelchtermans, G. (2005). Teachers' emotions in educational reforms: Self-understanding, vulnerable commitment and micropolitical literacy. Teaching and Teacher Education, 21, 995-1006. https://doi.org/10.1016/j.tate.2005.06.009

Kitchen, W. H. (2014). Authority and the teacher. London.

Koutrouba, K., Baxevanou, E., \& Koutroumpas, A. (2012). High school students perceptions of attitudes towards teacher power in the classroom. International Education Studies, 5(5), 185-198. https://doi.org/10.5539/ies.v5n5p185

Lai, C., Gu, M., \& Hu, J. (2015). Understanding legitimate teacher authority in a cross-cultural teaching context: pre-service Chinese language teachers undertaking teaching practicum in international schools in Hong Kong. International Research and Pedagogy, 41(4), 417-434. https://doi.org/10.1080/02607476.2015.1081717

Macleoda, G., Macallisterb, J., \& Pirriec, A. (2012). Towards a broader understanding of authority in student teacher relationships. Oxford Review of Education, 38(4), 493-508. https://doi.org/10.1080/03054985.2012.716006

Mccluskey, G., Lloyd, G., Kane, J., Stead, J., Riddell, S., \& Weedon, E. (2008). Can restorative practices in schools make a difference? $\quad$ Educational Review, 60(4), $405-417$. https://doi.org/10.1080/00131910802393456

Mclaughlin, H. H. (1991). Reconciling care and control: authority in classroom relationships. Journal of Teacher Education, 42(3), 182-195. https://doi.org/10.1177/002248719104200304

Metz, M. (1978). Classrooms and corridors: The crisis of authority in desegregated secondary schools. Berkeley: University of California Press. https://doi.org/10.1525/9780520314061

Mulder, M. (1977). The daily power game. Leiden, Netherlands: Martinus Nijhoff. https://doi.org/10.1007/978-1-4684-6951-6 
Munn, P., Sharp, S., Lloyd, G., Macleod, G., Mccluskey, G., Brown, J., ... Hamilton, L. (2011). A comparison of staff perceptions of behavior in Scottish schools in 2009 and 2006. Research Papers in Education, 28(2), 135-154. https://doi.org/10.1080/02671522.2011.600459

Nathan, D. B. (2012). Negotiating authority through jointly constructing the course curriculum. Teachers and Teaching, 18, 159-180. https://doi.org/10.1080/13540602.2012.632273

Neiman, A. (1986). Education, power, and the authority of knowledge. Teacher College Record, 88, 64-80.

Oakes, J., Gamoran, A., \& Page, R. (1992). Curriculum differentiation: Opportunities, outcomes, and meaning. In P. Jackson (Ed.), Handbook of research on curriculum (pp. 570-608). New York: Macmillan.

Oyler, C., \& Becker, J. (1997). Teaching beyond the progressive - traditional dichotomy: Sharing authority and sharing vulnerability. Curriculum Inquiry, 27, 453-467. https://doi.org/10.1111/0362-6784.00064

Pace, J. L. (2003a). Using ambiguity and entertainment to win compliance in a lower level U.S. history class. Journal of Curriculum Studies, 35, 83-110. https://doi.org/10.1080/00220270210157597

Pace, J. L. (2003b). Managing the dilemmas of professional and bureaucratic authority in a high school English class. Sociology of Education, 76, 37-52. https://doi.org/10.2307/3090260

Pace, J. L. (2003c). Revisiting classroom authority: Theory and ideology meet practice. Teachers College Record, 105, 1559-1585. https://doi.org/10.1111/1467-9620.00300

Pace, J. L. (2006). Saving (and losing) face, race, and authority: Strategies of action in a ninth-grade English class, J. Pace, \& A. Hemmings (Eds.). Mahwah: New Jersey: Lawrence Erlbaum Associates, Inc.

Pace, J., \& Hemmings, A. (2006). Classroom authority: theory, research, and practice. Mahwah: New Jersey: Lawrence Erlbaum Associates, Inc. https://doi.org/10.4324/9781410617163

Pace, J., \& Hemmings, A. (2007). Understanding authority in classrooms: A review of theory, ideology, and research. Review of Educational Research, 77(1), 4-27. https://doi.org/10.3102/003465430298489

Pellegrino, A. M. (2010). Pre-service teachers and classroom authority. American Secondary Education, 38(3), 62-78.

Peters, R. S. (1966). Ethics and education. London: Allen \& Unwin.

Richmond, V. P., \& Mccroskey, J. C. (1984). Power in the classroom II: Power and learning. Communication Education, 33(2), 125-136. https://doi.org/10.1080/03634528409384729

Ruddock, J., \& Flutter, J. (2000). Pupil participation and pupil perspective: carving a new order of experience. Cambridge Journal of Education, 30(1), 75-89. https://doi.org/10.1080/03057640050005780

Sedlak, M., Wheeler, C., Pullin, D., \& Cusick, P. (1986). Selling students short: Classroom bargains and academic reform in the American high school. New York: Teachers College Press.

Selznick, P. (1992). The moral commonwealth: Social theory and the promise of community. Berkeley: University of California Press.

Spady, W., \& Mitchell, D. (1979). Authority and the management of classroom activities. In The 78th Yearbook of the NSSE (pp. 75-115). Chicago, IL: University of Chicago Press.

Tirri, K., \& Puolimatka, T. (2000). Teacher authority in schools: a case study from Finland. Journal of Education for Teaching, 26(2), 157-165. https://doi.org/10.1080/02607470050127072

Tom, A. (1984). Teaching as a moral craft. New York: Longman.

Uitto, M., \& Syrja La, L. (2011). Body, caring and power in teacher-pupil relationships: encounters in former pupils' memories. Scandinavian Journal of Educational Research, 52(4), 355-371. https://doi.org/10.1080/00313830802184517

Van Manen, M. (1991). The tact of teaching: The meaning of pedagogical thoughtfulness. Albany: State University of New York Press.

Weber, M. (1947). The theory of social and economic organization. New York: Free Press.

Weber, M. (1978). The nature of charismas domination (E. Matthews, Trans.). In W. G. Runciman (Ed.), Max Weber selections in translation (pp. 226-250). New York: Cambridge University Press. https://doi.org/10.1017/CBO9780511810831.019

Weber, M. (2008). Politics as vocation (G. C. Wells, Trans.). In J. Dreijmanis (Ed.), Max Weber's complete 
writings on academic and political vocations (pp. 155-207). New York: Algora Publishing.

Wrong, D. (1980). Power: Its forms, bases and uses. New York: Harper Colophon.

\section{Copyrights}

Copyright for this article is retained by the author(s), with first publication rights granted to the journal.

This is an open-access article distributed under the terms and conditions of the Creative Commons Attribution license (http://creativecommons.org/licenses/by/4.0/). 